\title{
COMPOSITION OF VAGINAL MICROFLORA IN RELATION TO VAGINAL PH AND WET MOUNT DIAGNOSTIC TESTS IN THE FIRST TRIMESTER OF PREGNANCY
}

\author{
Jana Žodžika*,**, Dace Rezeberga*,**, Gilbert Donders***, Natālija Vedmedovska*, \\ Olga Vasina*,**, Ināra Pundure*, Ruta Bite*, Žanna Pavlova*, and Oksana Zīle*
}

* Department of Obstetrics and Gynecology, Rīga Stradiṇš University, Miera iela 45, Rīga, LV-1013, LATVIA; zodzika@inbox.lv.

** Department of Gynecology, Rīga Eastern Clinical University Hospital, Hipokrāta iela 2, Rīga, LV-1038, LATVIA

*** Department of Obstetrics and Gynecology, University of Antwerp, Prinsstraat 13, Antwerpen, BELGIUM

Communicated by Ludmila Vīksna

\begin{abstract}
The aim of the study was to determine the relations between vaginal culture results, elevated vaginal $\mathrm{pH}$ and abnormal vaginal microflora observed in microscopy, during the first trimester of pregnancy. A cross-sectional, observational study of 100 women receiving antenatal care in five outpatient clinics was carried out in Riga from March 2010 until April 2011. Pregnant women at the first antenatal visit were submitted to a vaginal specimen collection for $\mathrm{pH}$ measurement, wet mount and cultures. Fifty pregnant women with vaginal $\mathrm{pH} 4.5$ and 50 subsequent pregnant women with vaginal $\mathrm{pH}$ less than 4.5 were included. $96 \%$ of women with increased $\mathrm{pH}$ and $86 \%$ of women with normal vaginal $\mathrm{pH}$ showed positive cultures. Increased vaginal $\mathrm{pH}$ was significantly associated with $\mathrm{M}$. hominis $(\mathrm{P}<0.001)$, $\mathrm{U}$. urealyticum $(\mathrm{P}=0.017)$ and $\mathrm{E}$. coli $(\mathrm{P}=0.018)$. Abnormal vaginal microflora patterns showed similar associations with culture findings. Multivariate logistic regression analysis showed the highest risk of abnormal vaginal microflora associated with $\mathrm{M}$. hominis (OR 14.4, 95\% Cl 1.6-124.4, $\mathrm{P}=0.015)$ and $\mathrm{E}$. coli $(\mathrm{OR} 8.5,95 \% \mathrm{Cl}$ 1.6-45.9, $\mathrm{P}=0.013$ ). Increased vaginal $\mathrm{pH}$ and abnormal vaginal microflora pattern in wet mounts was associated with $\mathrm{M}$. hominis and $\mathrm{E}$. coli in vaginal cultures.
\end{abstract}

Key words: vaginal $\mathrm{pH}$, wet mount, abnormal vaginal microflora, pregnancy.

\section{INTRODUCTION}

In many clinical settings proper diagnostic monitoring of vulvovaginal symptoms and/or risk assessment of the vaginal microflora to prevent gestational complications are poorly developed or non-existing (Msuya et al., 2009). Some obstetricians rely only on syndromic management, while others make vaginal cultures on all pregnant women and (over)treat them with antibiotics.

Although there is strong evidence that microscopic findings indicating abnormal vaginal microflora (AVM) are associated with complications in pregnancy, such as preterm birth, chorionamnionitis and preterm rupture of the membranes (Hay et al., 1994; Donders et al., 2008), there is no consensus on using culture results as a substitute for these findings. We strongly object to start treatment based solely on culture of vaginal microorganisms, as this leads to overtreatment, exposes the mother and foetus to unnecessary toxins, increases the risk of bacterial antimicrobial resistance in both mother and new-born, and enhances the risk of hard to treat, recurrent vulvovaginal candidosis, along with other disturbances of the vaginal ecology.

Since there is growing evidence that treatment of AVM with adequate antibiotics in early pregnancy can prevent at least part of infections-related preterm birth (Ugwumadu et al., 2004; Lamont et al., 2005), moreover, in patients with a history of adverse pregnancy outcomes (Thinkhamrop et al., 2009), it might be crucial to identify pregnant women with high AVM risk, who need early diagnostic and management of abnormal vaginal microflora. According to guidelines of the Latvian Association of Gynecologists and Obstetricians, one of the most common AVM types, bacterial vaginosis (BV), should be diagnosed if three out of four Amsel criteria are present (Amsel et al., 1983). To evaluate them gynecologists need to examine vaginal discharge appearance, use vaginal $\mathrm{pH}$ strips and take samples for microscopy: bed-side wet mount or send for Gram stain microscopy. In Latvia, upper vaginal smears are taken for Gram staining for all pregnant women, in order to exclude gonorrhoea and to evaluate vaginal microflora, although waiting for results 
takes additional time and visits. Immediate diagnostic of AVM during the first antenatal visit by using bed-side diagnostic tests, such as vaginal $\mathrm{pH}$ test and wet mount microscopy, could accelerate this process. In fact, in Latvia gynecologists do not often use vaginal $\mathrm{pH}$ strips, are not skilled to perform wet mounts, and commonly BV diagnosis is based solely on positive clue cells or even only presence of Gardnerella vaginalis morphotypes on Gram stain laboratory reports.

All applied diagnostic methods should be based on indications and validity of all tests should be clear, since unnecessary analysis and controversial results increase stress and anxiety in pregnant women. All women have the right to receive complete, evidence-based information about the performed tests, their specificity, sensitivity and possible influence of results on pregnancy care, risks and benefits.

In order to identify the microorganisms that are commonly associated with abnormal vaginal environment, we determined the relations of vaginal culture results with bed-side diagnostic test findings - elevated vaginal $\mathrm{pH}$ and abnormal vaginal microflora on wet mounts, during the first trimester of pregnancy.

\section{MATERIALS AND METHODS}

We performed a cross-sectional, observational study of 100 women receiving antenatal care in five outpatient clinics in Rīga from March 2010 until April 2011, as part of an ongoing interventional study.

The study was approved by the Ethical Committee of the Rīga Stradinšs University. All participants were informed about the study and signed an informed consent. 50 pregnant women with fetal gestational age between 6 and 14 weeks and vaginal $\mathrm{pH} \geq 4.5$ were included as study cases and subsequently 50 pregnant women within the same gestational age range and vaginal $\mathrm{pH}$ less than 4.5 were used as a control. Exclusion criteria were age less than 18 years, multiple pregnancy and systemic diseases (diabetes, kidney failure, chronic hypertension requiring medication etc). All women were tested for Chlamydia trachomatis, gonorrhoea, HIV and syphilis infections and were excluded if positive for any of them.

During the gynecological speculum examination vaginal fluid was obtained with cytobrush from the upper vaginal wall and spread on a glass slide for microscopic examination. Vaginal $\mathrm{pH}$ was measured by pressing a Machery Nagel $\mathrm{pH}$ strip with a $\mathrm{pH}$ range of 3.1-7 into the fluid on a glass slide, allowing it to soak for 10 seconds. These strips were chosen because of their accuracy and ease of use (Donders et al., 2007). Vaginal $\mathrm{pH} \geq 4.5$ was considered abnormal (elevated) (Amsel et al., 1983).

Vaginal discharge specimens were spread on glass slides, air-dried and then transported to one investigator (Jana Žodžika) for microscopy after rehydration of the smear with a droplet of saline according to Larsson (Larsson et al.,
1990). A Leica DM1000 microscope (Warburg, Germany) with phase contrast at 400 times magnification was used. Microscopic examination included lactobacillary grades (LBG) and number of leucocytes per high power field (hpf): less than 10 - no leucocytosis; more than 10 per hpf, but less than 10 per epithelial cell-mild leucocytosis; 10 or more per epithelial cell-heavy leucocytosis (Donders, 1999). According to Donders' modification of Schroder's' classification LBG, grade I consisted of predominant presence of Lactobacillus morphotypes, with very few coccoid bacteria presented, grade IIa (intermediate, mixed flora) of lactobacilli outnumbering other microorganisms, grade IIb of other microorganisms outnumbering lactobacillary morphotypes, and grade III (completely disturbed flora) had no lactobacilli present (Donders, 1999). LBG III was further divided in three subgroups: bacterial vaginosis (BV), aerobic vaginitis (AV) and a mixed $\mathrm{AV}-\mathrm{BV}$ microflora. AV was diagnosed if short bacilli or cocci, leucocytes and/or parabasal cells were found (Donders, 2002). Patterns with decreased or absent lactobacillus morphotypes (LBG IIb and LBG III) were considered as AVM (Donders, 1999).

For all participants included in the culture study, specimens taken from the upper vaginal wall with wool cotton-tipped swabs were immediately placed in universal Amies medium and transported within 24 hours to the laboratory of the Infectology Center of Latvia. Then the samples were inoculated in media Shaedler blood agar, MacConkey agar, eggsalt agar, chocolate and Chromagar Candida agar for the investigation of the following microorganisms: Streptococcus pyogenes (Str. pyogenes), Streptococcus agalactiae (Str. agalactiae), Viridans group streptococci, enterococci, $S$. aureus, Candida spp. (species), pathogenic enteric bacteria, Acinetobacter spp., Haemophilus spp., Pseudomonas aeroginosa and Stenotrophomonas maltophilia. To distinguish between Str. pyogenes, Str. agalactiae, and Viridans group streptococci, several specific enterococci tests were made. Streptococci were cultivated on blood agar to determine their degree of haemolysis. If $\beta$-haemolysis was present, then susceptibility to bacitracin was tested, which if positive, Str. pyogenes was considered to be present. If the test was negative, then the CAMP (Christie-Atkins, MunchPetersen) test was performed; a positive was considered as presence of Str. agalactiae. If on blood agar $\alpha$-hemolysis was observed, then a further test for optochin susceptibility was made; if negative, then the culture was inoculated on Bile-esculin media. If no growth occurred, then the culture was considered as Viridans group streptococci, but if there was growth, then the culture were further cultivated on $6.5 \%$ salt media: if there was growth then the culture was identified as enterococci. If on blood agar no haemolysis was observed, then the cultures were cultivated on Bileesculin agar, and in case of positive growth on this media and on $6.5 \%$ salt agar the culture was considered to be enterococci (Levinson, 2008).

To distinguish between Haemophilus species, testing for $\mathrm{X}$ and $\mathrm{V}$ factor requirements was performed using impregnated strips (Mahon et al., 2000). 
Urea-Arginine broth was used for the investigation of Ureaplasma urealyticum and Mycoplasma hominis (Mahon et al., 2000). Cultures with more than $10^{5} \mathrm{cfu} / \mathrm{ml}$ (colony forming unit) of $U$. urealyticum and $M$. hominis were considered elevated (Rosenstein et al., 1996).

Vaginal culture results were compared between normal and elevated vaginal $\mathrm{pH}$ groups, normal and abnormal vaginal microflora groups and no leucocytosis and mild, heavy leucocytosis groups based on microscopy results.

Statistical significance was tested using the Pearson chisquare test or Fisher's exact test. The level of statistical significance was chosen at 5\% $(P<0.05)$. Only variables that showed statistical significance $(P<0.05)$ in univariate analysis were included in the multiple logistic regression analysis. Statistical analysis was performed using SPSS version 18.0 (PASW).

\section{RESULTS}

$96 \%$ of women with increased $\mathrm{pH}$ and $86 \%$ of women with normal vaginal $\mathrm{pH}$ showed positive cultures ( $P$ value nonsignificant). In total 19 different microorganisms were recovered from the vagina. Of 100 participants, the more common isolated microorganisms were coagulase negative (CN) Staphylococcus in 56, U. urealyticum in 34, Escherichia coli (E. coli) in 18, Candida species in 16 and $M$. hominis in 15 cases.

Increased vaginal $\mathrm{pH}$ was significantly associated with positive $M$. hominis $(P<0.001), U$. urealyticum $(P=0.017)$, and $E$. coli $(P=0.018)$ cultures. Correlations of abnormal vaginal microflora microscopic patterns with cultures were similar to those with elevated $\mathrm{pH}$, Table 1 .
LBG I was found in 35, LBG IIa in 14, LBG IIb in 17 and LBG III in 34 participants. Of the latter, eight had BV, five had AV and 21 had mixed BV-AV microflora. Forty-three of 50 participants with elevated vaginal $\mathrm{pH}$ and six of 50 pregnant women with normal vaginal acidity had AVM on microscopy $(P<0.001)$. U. urealyticum and $M$. hominis were more often found in the BV and mixed BV-AV microflora $(P<0.05)$ than in other microflora types, and all cases with high numbers of $M$. hominis were encountered in women with LBG III $(P=0.001)$. E c coli was more often detected in the AVM group $(P=0.008)$, with a trend to be more often recovered in cases with LBG IIb, AV and mixed BV-AV microflora $(P=0.072)$. Str. agalactiae $(P=0.032)$ and Viridans group streptococci $(P=0.013)$ were more often found in association with normal vaginal microflora patterns (Table 1).

Combining both vaginal environment parameters (vaginal $\mathrm{pH}$ and microflora type on microscopy), 43 participants had a normal pattern (acidic vaginal $\mathrm{pH}$ and LBG I-IIa) and 44 pregnant women had an abnormal pattern (elevated vaginal $\mathrm{pH}$ and LBG IIb-III) (Table 2). Considering only statistically significant variables of these groups in the univariate analysis, $U$. urealyticum (OR 3.1, 95\% CI 1.2-8.2, $P=$ 0.019), M. hominis (OR 18, 95\% CI 2.2-145.2, $P<0.001$ ) and $E$. coli (OR 7.5, 95\% CI 1.64-37.6, $P=0.008$,) occurred more often in the abnormal environment group (Table 2). However, with high numbers of M. hominis it was not possible to calculate the significance level, as all cases were cultured in the AVM group. The univariate analysis did not find a strong Str. agalactiae and Viridans group streptococci association with normal microflora and acidity group. Comparison of culture results in the groups with no, mild or heavy leucocytosis demonstrated that E. coli was significantly associated with increased number of leucocytes on native microscopy $(P=0.03)$.

Table 1

VAGINAL CULTURE RESULTS IN NORMAL AND ELEVATED VAGINAL PH GROUPS AND IN LBG GROUPS

\begin{tabular}{|c|c|c|c|c|c|c|c|c|c|}
\hline \multirow[b]{2}{*}{ Cultured microbes } & \multirow[b]{2}{*}{ Total } & \multicolumn{2}{|c|}{ Vaginal $\mathrm{pH}$} & \multirow{2}{*}{$P$ value } & \multicolumn{4}{|c|}{ LBG } & \multirow[b]{2}{*}{$P$ value } \\
\hline & & $\begin{array}{c}\mathrm{pH}<0.5 \\
\mathrm{n}=50\end{array}$ & $\begin{array}{c}\mathrm{pH} \geq 4.5 \\
\mathrm{n}=50\end{array}$ & & $\begin{array}{c}\mathrm{I} \\
\mathrm{n}=35\end{array}$ & $\begin{array}{c}\text { IIa } \\
\mathrm{n}=14\end{array}$ & $\begin{array}{c}\mathrm{IIb} \\
\mathrm{n}=17\end{array}$ & $\begin{array}{c}\text { III } \\
\mathrm{n}=34\end{array}$ & \\
\hline U. urealyticum & 34 & 10 & 24 & $0.017 *$ & 7 & 5 & 2 & 20 & 0.002 \\
\hline U. urealyticum (high numbers) & 15 & 3 & 12 & $0.023 *$ & 2 & 2 & 0 & 11 & 0.006 \\
\hline M. hominis & 15 & 1 & 14 & $<0.001 *$ & 0 & 1 & 0 & 14 & $<0.001$ \\
\hline Str. agalactiae & 6 & 2 & 4 & 0.678 & 2 & 1 & 3 & 0 & 0.032 \\
\hline Coagulase positive (CP) Staphylococcus & 4 & 1 & 3 & 0.618 & 1 & 0 & 1 & 2 & 0.896 \\
\hline CN Staphylococcus & 56 & 27 & 29 & 0.618 & 18 & 10 & 8 & 20 & 0.172 \\
\hline Str. viridians & 9 & 6 & 3 & 0.193 & 4 & 4 & 0 & 1 & 0.013 \\
\hline Peptostrepto-coccus & 2 & 2 & 0 & 0.238 & 2 & 0 & 0 & 0 & 0.734 \\
\hline E. coli & 18 & 4 & 14 & $0.018^{*}$ & 1 & 3 & 7 & 7 & 0.001 \\
\hline Enterobacteri-aceae & 2 & 1 & 1 & 1.000 & 0 & 0 & 1 & 1 & 0.476 \\
\hline Acinetobacter spp & 4 & 0 & 4 & 0.121 & 1 & 0 & 1 & 2 & 0.896 \\
\hline Candida spp & 16 & 8 & 8 & 1.000 & 7 & 0 & 4 & 5 & 0.265 \\
\hline
\end{tabular}


Table 2

VAGINAL CULTURES RESULTS IN NORMAL AND ABNORMAL VAGINAL MICROFLORA AND ACIDITY GROUPS

\begin{tabular}{|c|c|c|c|}
\hline $\begin{array}{c}\text { Cultured } \\
\text { microorganisms }\end{array}$ & $\begin{array}{c}\text { Normal vaginal } \\
\text { microflora, acidity } \\
\text { group: } \\
\text { pH }<4.5 \text { and } \\
\text { LBG I-IIa } \\
(\mathrm{n}=43)\end{array}$ & $\begin{array}{c}\text { Abnormal vaginal } \\
\text { microflora, acidity } \\
\text { group: } \\
\text { pH } \geq 4.5 \text { and } \\
\text { LBG IIb-III } \\
(\mathrm{n}=44)\end{array}$ & $P$ value \\
\hline U. urealyticum & 9 & 21 & 0.019 \\
\hline $\begin{array}{l}\text { U. urealyticum } \\
\text { (high numbers) }\end{array}$ & 3 & 11 & 0.043 \\
\hline M. hominis & 1 & 14 & $<0.001$ \\
\hline $\begin{array}{l}\text { M. hominis } \\
\text { (high numbers) }\end{array}$ & 0 & 9 & 0.003 \\
\hline Str. agalactiae & 2 & 3 & 1.000 \\
\hline CP Staphylococcus & 0 & 2 & 0.496 \\
\hline CN Staphylococcus & 25 & 26 & 0.600 \\
\hline Str. viridians & 6 & 1 & 0.047 \\
\hline Peptostreptococcus & 2 & 0 & 0.210 \\
\hline $\begin{array}{l}\text { Enterococcus } \\
\text { faecalis }\end{array}$ & 2 & 3 & 1.000 \\
\hline Enterobacteriaceae & 0 & 1 & 1.000 \\
\hline Acinetobacter spp & 0 & 3 & 0.243 \\
\hline Candida spp & 6 & 7 & 0.957 \\
\hline
\end{tabular}

Table 3

ASSOCIATION OF DIFFERENT BACTERIA WITH ABNORMAL VAGINAL MICROFLORA AND VAGINAL $\mathrm{pH}$ IN MULTIVARIATE LOGISTIC REGRESSION ANALYSIS

\begin{tabular}{|c|c|c|c|c|}
\hline $\begin{array}{c}\text { Cultured } \\
\text { microorganisms }\end{array}$ & OR & $\begin{array}{c}\text { Standard } \\
\text { error }\end{array}$ & $P$ value & $95 \% \mathrm{CI}$ \\
\hline U. urealyticum & 2.6 & 1.7 & 0.155 & $0.7-9.5$ \\
\hline $\begin{array}{l}\text { U. urealyticum } \\
\text { (high numbers) }\end{array}$ & 1.2 & 1.2 & 0.802 & $0.2-7.9$ \\
\hline M. hominis & 14.4 & 15.8 & 0.015 & $1.6-124.4$ \\
\hline E. coli & 8.5 & 7.3 & 0.013 & $1.6-45.9$ \\
\hline
\end{tabular}

Multivariate logistic regression analysis showed that the highest risk of AVM was associated with $M$. hominis and $E$. coli (Table 3).

\section{DISCUSSION}

According to our results, it is clear that proportions of positive vaginal cultures were above $85 \%$ in both normal and AVM groups, including all types of aerobic and anaerobic bacteria. Therefore, treating any positive culture obtained from the vagina should never be an option in pregnant women. Pregnant women with elevated vaginal $\mathrm{pH}$ and AVM on native microscopy, a recognized risk factor for adverse pregnancy outcome, were more likely to have $M$. hominis, U. urealyticum, E. coli positive vaginal cultures, while Str. agalctiae and Viridans group streptococci were more related to normal vaginal microflora. Vaginal leucocytosis was significantly associated with $E$. coli coloniation.
Although the association between $U$. urealyticum, $M$. hominis and pregnancy complications, such as late miscarriages, preterm birth, low birth weight and neonatal respiratory diseases (Steytler, 1970; Hay et al., 1994; Taylor-Robinson et al., 2007; Romero et al., 2008; Donders et $a l ., 2009)$ is well established, it is still unclear which pregnant women would benefit from cultures and treatment of these bacteria. U. urealyticum, M. hominis, E. coli, and Str. agalactiae commonly inhabit the lower genital tract of sexually active women (Watt et al., 2003; Waits et al., 2005; Barcaite et al., 2008). Large numbers of M. hominis are associated with BV and are an important risk factor for development of preterm labour (Lamont et al., 1987; Rosenstein et al., 1996). Considerable efforts have been dedicated to study antimicrobial therapy as an intervention to prevent preterm birth. Several authors have evaluated the role of antibiotics to prevent preterm birth in BV cases. Clindamycin administered early in the second trimester to women who test positive for BV seemed to be more effective than metronidazole to reduce preterm birth rate (Carey et al., 2000; Ugwumadu et al., 2004; Lamont et al., 2005), probably because it has a larger scale antibacterial activity against anaerobic gram-negative, aerobic gram-positive bacteria and also M. hominis (Mylonas, 2010; Taylor-Robinson et al., 2010). Not only metronidazole and clindamycin have been studied (Hauth et al., 1995; Lamont, 2005). Randomised controlled studies of $\beta$ lactams and azithromycin as mono-therapy have not shown any benefit, although combination of $\beta$ lactams and metronidazole, erythromycin and metronidazole in the second trimester of pregnancy have been shown to slightly reduce preterm birth risk, although no large studies have been performed (Subramaniam et al., 2012).

In our study high numbers of $M$. hominis were found only in cases of AVM and had the strongest association with pathological vaginal environment. The association of $U$. urealyticum with decreased lactobacilli and elevated vaginal $\mathrm{pH}$ was by far less strong than for M. hominis. Hence, we postulate that merely the fact of vaginal colonisation with $U$. urealyticum and/or M. hominis per se is a poor predictor of an abnormal pregnancy outcome, but high density vaginal mycoplasma colonisation, and its associated microflora abnormalities, should be considered a risk factor for chorionamnionitis and preterm birth. Other studies have confirmed that only a high load of ureaplasmas is related to adverse pregnancy outcomes (Abele-Horn et al., 2000; Kasper et al., 2010).

In the present study abnormal vaginal $\mathrm{pH}$ was associated not only with $\mathrm{BV}$, but also with AV microflora, while $M$. hominis and $U$. urealyticum both were more often found in women with $\mathrm{BV}$ and with mixed $\mathrm{AV}-\mathrm{BV}$ microflora; $E$. coli was more typically cultured in LBG IIb and AV microflora and furthermore associated with increased leucocytosis. These results are similar to those of another study, in which E. coli growth was inhibited by Lactobacillus strains (Juarez-Tomas et al., 2003). Our findings are in line with those of Donders et al. (2000), who defined an entity of 
AVM that is different from bacterial vaginosis: aerobic vaginitis, also to be considered as an independent risk factor for preterm delivery (Donders et al., 2009). Surprisingly, some specific aerobic pathogenic bacteria, like Str. viridians, which can have a role in the pathogenesis of amniotic infections, were more often found in the normal vaginal microflora group in these series (Ariel et al., 1991). Contrary to these findings, this group of bacteria has been associated with AVM and reduced lactobacilli in other studies (Hillier, 1993). Both Lactobacillus, Streptococcus genera belong to the order Lactobacillales (lactic acid bacteria), which ferment glucose to lactic acid and therefore might be associated with an acidic environment. They are normal microflora in humans in the oral cavity, the intestinal tract and the vagina, where they play a beneficial role (Todar, 2012). Compared to some other authors (Barcaite et al., 2008), we found a lower prevalence of Str. agalactiae (6\%), probably because the samples were taken from upper vagina not from lower part of vagina, perineum and rectum. The observed incidence was similar to those reported in earlier studies performed in Latvia with the same methodology (Rezeberga et al., 2000).

Not only BV, but also aerobic vaginitis in early pregnancy is linked to preterm deliveries and chorionamnionitis (Rezeberga et al., 2008; Donders et al., 2008; 2009). Since the extent of the inflammatory reaction has a particularly important role in the pathogenesis of preterm deliveries (Jacobson et al., 2003), the association of E. coli in the presence of leucocytosis found in our study can be important. Increased vaginal leucocytosis is associated with higher concentration of pro-inflammatory cytokines present in the vagina and with enzymatic activity, leading to preterm contractions and intrauterine infections (Donders et al., 2002; Romero et al., 2002; Larsson et al., 2006). A study of metronidazole treatment of AVM in pregnancy showed no benefit from this treatment - even worse — rates of preterm birth increased in the metronidazole group, which was explained by increased E. coli and Klebsiella pneumoniae in the vagina at delivery (Carey et al., 2005). Besides their association with prematurity, Str. agalactiae and E. coli are also a major cause of early neonatal infection (Stoll et al., 2011). Many authors have recognised the increasing role of E. coli in the development of early neonatal disease and sepsis, especially in preterm babies (Lin et al., 2011). Although in the present study E. coli and M. hominis colonisation was strongly associated with decreased or absent Lactobacillus morphotypes on microscopy and increased vaginal $\mathrm{pH}$, the association could be less strong in a larger population, due to the wide confidence intervals found.

It is interesting that Candida species colonisation was found with the same frequency in the both normal and abnormal vaginal microflora groups and was not statistically significantly associated with heavy leucocytosis. This demonstrates that candidas can exist in different vaginal environments and can be a part of co-infection. The predominance of Candida colonisation in reproductive age women, and its infrequent occurrence in children and menopausal women, strongly suggests that colonisation is hormone-dependent. Estrogens promote elevated glycogen production by vaginal epithelial cells, which is the primary nutrient source for Candida. Conditions associated with elevated hormone production (pregnancy, diabetes, oral contraception) are associated with increased growth of Candida. Conversion of an asymptomatic Candida colonisation to a symptomatic infection following the ingestion of antibiotics, strongly implicates the vaginal microflora, particularly Lactobacillus species, in down regulation of the ability of Candida to proliferate (Ledger et al., 2010). Since Candida colonisation does not cause inflammation, after exclusion of sexually transmitted infections, presence of aerobic bacteria was associated with heavy leucocytosis in our study.

During the first antenatal visit in case of clinical indications like signs/symptoms of genital infections, history of miscarriage and preterm deliveries (Thinkhamrop, 2009), for rapid and early diagnosis of AVM we recommend to perform vaginal $\mathrm{pH}$ tests and wet mount, since these tests can indicate overgrowth of potential pathogens like M. hominis and E. coli. We hypothesise that treatment should be based according to abnormal vaginal microflora type, susceptible to $M$. hominis in $\mathrm{BV}$ and to $E$. coli in $\mathrm{AV}$ associated cases, or, alternatively, to non-antibacterial, broad spectrum antimicrobial medication. Prospective studies are needed to confirm the importance of $E$. coli and $M$. hominis, and perhaps $U$. urealyticum in risk assessment of preterm birth and neonatal sepsis in women with AVM patterns and increased $\mathrm{pH}$, and effect of AVM type specific treatment on preterm birth reduction.

However, as vaginal $\mathrm{pH}$ and microflora can be normal in Str. agalactiae colonisation cases, bed-side tests do not replace detection of Str. agalactiae by cultures in the pregnant women population.

We conclude that AVM on wet mount and vaginal $\mathrm{pH}$ in the first trimester of pregnancy is associated with $M$. hominis and $E$. coli overgrowth in cultures. Increased vaginal $\mathrm{pH}$ is associated both with bacterial vaginosis and aerobic microflora. Microscopy of vaginal fluid is necessary to recognise AVM types. We suggest bed-side native microscopy for this purpose, as it allows the gynecologist to exam vaginal specimens and commence immediate therapeutic action.

\section{ACKNOWLEDGEMENTS}

We thank Irēna Rogovska, MD, PhD, from Rīga Stradin̄̌ University for help with the statistical analysis and the women who agreed to participate in the study.

Supported by a grant from the Latvian Ministry of Education and Science (IZM RSU-ZP 07-5) and the European Social Fund.

\section{REFERENCES}

Abele-Horn, M., Scholz, M., Wolff, C., Kolben, M. (2000). High-density vaginal Ureaplasma urealyticum colonization as a risk factor for 
chorioamnionitis and preterm delivery. Acta Obstet. Gynecol. Scand., 79, 973-978.

Amsel, R., Totten, P. A., Spegiel, C. A. (1983). Nonspecific vaginitis. Diagnostic criteria and microbial and epidemiologic associations. Amer. J. Med., 74, 14-22.

Ariel, I., Singer, D. B. (1991). Streptococcus viridans infections in midgestation. Pediatr. Pathol., 11 (1), 75-83.

Barcaite, E., Bartusevicius, A., Tameliene, R., Kliucinskas, M., Maleckiene, I., Nadisauskiene, R. (2008). Prevalence of maternal group B streptococcal colonisation in Europian countries. Acta Obstet. Gynecol. Scand., 87 (3), 260-271.

Carey, J., Klebanoff, M. A., Hauth, J. C., Hillier, S. L., Thom, E. A., Ernest, J. M. (2000). Metronidazole to prevent preterm delivery in pregnant women with asymptomatic bacterial vaginosis. New Engl. J. Med., 342, 534-540.

Carey, J., Christopher, M. D., Klebanoff, M. A. (2005). Is change in the vaginal flora associated with an increased risk of preterm birth? Amer. J. Obstet. Gyn., 192 (4), 1341-1347.

Donders, G. G. (1999). Microscopy of bacterial flora on fresh vaginal smears. Infect Dis Obstet. Gynecol., 7, 126-127.

Donders, G. G., Van, B. B, Caudron, J., Londers, L., Vereecken, A., Spitz, B. (2000). Relationship of bacterial vaginosis and mycoplasmas to the risk of spontaneous abortion. Amer. J. Obstet. Gynecol., 183, 431-437.

Donders, G. G., Vereecken, A., Bosmans, E., Dekeersmaecker, A., Salembier, G., Spitz B. (2002). Aerobic vagintis: abnormal vaginal flora entity that is distinct from bacterial vaginosis. $B J O G, \mathbf{1 0 9}, 1-10$.

Donders, G. G., Caeyers, T., Tydhof, P., Riphagen, I., Van den Bosch, T., Bellen, G. (2007). Comparison of two types of dipsticks to measure vaginal pH in clinical practice. Eur. J. Obstet. Gynecol. Reprod. Biol., 134 (2), $220-224$

Donders, G. G., Spitz, B., Vereecken, A., Van Bulck, B. (2008). The ecology of the vaginal flora at first prenatal visit is associated with preterm delivery and low birth weight. Open Inf. Dis. J., 2, 45-51.

Donders, G. G., Van Calsteren, K., Reybrouck, R., Van den Bosch, T., Riphagen, I., Van Lierde, S. (2009). Predictive value for preterm birth of abnormal vaginal flora, bacterial vaginosis and aerobic vaginitis during the first trimester of pregnancy. BJOG, 116 (10), 1315-1324.

Hauth, J. C., Goldenberg, R. L., Andrews, W. W., Dubard, M. B., Cooper, R. L. (1995). Reduced incidence of preterm delivery with metronidazole and erithromycin in women with bacterial vaginosis. New Engl. J. Med., 333 (26), 1732-1736.

Hay, P. E., Lamont, R. F., Taylor-Robinson, D., Morgan, D.J., Ison, C., Pearson, J. (1994). Abnormal bacterial colonisation of the genital tract and subsequent preterm delivery and late miscarriage. BMJ, 308 (6924), $295-298$

Hiller, S. L., Krohn, M. A., Rabe, L. K., Klebanoff, S. J., Eschenbach, D. A. (1993). The normal vaginal flora, H2O2-producing lactobacilli, and bacterial vaginosis in pregnant women. Clin. Infect. Dis., 16 (4), S273-81.

Jacobsson, B., Mattsby-Baltzer, I., Andresch, B., Bokstrøm, H., Nikolaitchoul, N., Wennerholm, U. B., Hagberg, H. (2003). Microbial invasion and cytokine response in amniotic fluid in a Swedish population of women with preterm prelabor rupture of membranes. Acta Obstet. Gynecol. Scand., 82 (5), 423-431.

Juárez Tomás, M. S., Ocaña, V. S., Wiese, B., Nader-Macías, M. E. (2003). Growth and lactic acid production by vaginal Lactobacillus acidophilus CRL 1259, and inhibitionof uropathogenic Escherichia coli. J. Med. Microbiol., 52, 1117-1124.

Kasper, D. C., Mechtler, T. P., Reischer, G. H., Witt, A., Langgartner, M., Pollak, A., Herkner, K. R., Berger, A. (2010). The bacterial load of Ureaplasma parvum in amniotic fluid is correlated with an increased intrauterine inflammatory response. Diagn. Microbiol. Infect. Dis., 67 (2), $117-121$
Lamont, R. F., Taylor-Robinson, D., Wigglesworth, J. S., Furr, P. M., Evans, R. T., Elder, M. G. (1987). The role of mycoplasmas, ureaplasmas and chlamydia in the genital tract of women presenting in spontaneus early preterm delivery. J. Med. Microbiol., 24, 253-257.

Lamont, R. F. (2005). Can antibiotics prevent preterm birth-the pro and con debate. BJOG, 112 (1), 67-73.

Larsson, P. G., Platz-Christensen, J. J. (1990). Enumeration of clue cells in rehydrated air-dried vaginal wet smears for the diagnosis of bacterial vaginosis. Obstet. Gynecol., 76, 727-730.

Larsson, P. G., Fahraeus, L., Carlsson, B., Jakobsson, T., Forsum, U. (2006). Late miscarriage and preterm birth after treatment with clindamycin: A randomized consent design study according to Zelen. BJOG, 113, 629-637.

Ledger, W. J., Witkin, S. S. (2010). Vulvovaginal Infections. London, UK: Manson Publishing Ltd. 620 pp (at p. 52).

Levinson, W. (2008). Review of Medical Microbiology and Immunology. $10^{\text {th }}$ edn. The McGraw-Hill Companies, USA.

Lin, C. Y., Hsu, C. H., Huang, F. Y., Chang, J. H., Hung, H. Y., Kao, H. A., Peng, C. C., Jim, W. T., Chi, H., Chiu, N. C., Chang, T. Y., Chen, C. Y., Chen, C. P. (2011). The changing face of early-onset neonatal sepsis after the implementation of a maternal group B Streptococcus screening and intrapartum prophylaxis policy-a study in one medical center. Pediatr. Neonatol., 52 (2), 78-84

Mahon, C. R., Manuselis, G. (2000). Textbook of Diagnostic Microbiology. Phyladelphia: W.B. Saunders Company. 1230 pp.

Msuya, S. E., Uriyo, J., Stray-Pedersen, B., Sam, N. E., Mbizvo, E. M. (2009). The effectiveness of a syndromic approach in managing vaginal infections among pregnant women in northern Tanzania. East Afr. J. Public Health., 6 (3), 263-267.

Mylonas, I. (2010). Antibiotic chemotherapy during pregnancy and lactation period: Aspects for consideration. Arch. Gynaecol. Obstet., 283, 7-18.

Rezeberga, D., Lazdāne, G., Kroiča, J., Sokolova, L. (2000). Seksuāli transmisīvo slimību sastopamība grūtniecēm Latvijā [Incidence of sexually transmissive diseases in pregnant women in Latvia]. RSU Zinātniskie raksti, Rīga, 159-164.

Rezeberga, D., Lazdane, G., Kroica, J., Sokolova, L., Donders, G. G. (2008). Placental histological inflammation and reproductive tract infections in a low risk pregnant population in Latvia. Acta Obstet. Gynecol. Scand., 87 (3), 360-365.

Romero, R., Espinoza, J., Chaiworapongsa, T., Kakache, K. (2002). Infection and prematurity and the role of preventive strategies. Semin. Neonatol., 7 (4), 259-274.

Romero, R., Garite, T. J. (2008). Twenty percent of very preterm neonates (23-32 weeks of gestation) are born with bacteremia caused by genital mycoplasmas. Amer. J. Obstet. Gynecol., 198, 1-3.

Rosenstein, I. J., Morgan, D. J., Sheehan, M., Lamont, R. F., Taylor-Robinson, D. (1996). Bacterial vaginosis in pregnancy: Distribution of bacterial species in different Gram stain categories of the vaginal flora. J. Med. Microbiol., 45, 120-126.

Steytler, J. G. (1970). Studies on endogenous infection by vaginal mycoplasma based on positive cord-blood cultures. South Afr. J. Obstet. Gynaecol., 8, 14-22.

Stoll, B. J., Sanchez, P. J., Faix, R. G., Hansen, N. I., Poindexter, B. B., Van Meurs K. P. (2011). Early onset neonatal sepsis: The burden of group B streptococcal and E. coli continues. Pediatrics, 126 (5), 817-826.

Subramaniam, A., Abramovici, A., Andrews, W. W., Tita, A. T. (2012) Antimicrobials for preterm birth prevention: An overview. Infect. Dis. Obstet. Gynecol. DOI 10.1155/2012/157159.

http://www.ncbi.nlm.nih.gov/pmc/articles/PMC3296158/ (last accessed 25 February 2013)

Taylor-Robinson, D. (2007). The role of mycoplasmas in pregnancy outcome. Best Pract. Res. Clin. Obstet. Gynaecol., 21, 425-438. 
Taylor-Robinson, D., Lamont, R. F. (2010). Mycoplasmas in pregnancy. BJOG, 118, 164-174

Thinkhamrop, J., Hofmeyr, G. J., Adetoro, O., Lumbiganon, P. (2009). Prophylactic antibiotic administration during second and third trimester in pregnancy for prevention infectiuos morbidity and mortality. Cochrane Database of Systematic Reviews, CD 002500.

Todar K. Todar's Online Textbook of Bacteriology (2008-2012). http://textbookofbacteriology.net/lactics.html (last accessed 13 January 2013).
Ugwumadu, A., Reid, F., Hay, P., Manyonda, I. (2004). Natural history of bacterial vaginosis and intermediate flora in pregnancy and effect of oral clindamycin. Obstet. Gynecol., 104, 114-119.

Watt, S., Lanotte, P., Mereghetti, L., Moulin-Schouleur, M., Picard, B., Quentin, R. (2003). Escherichia coli strains from pregnant women and neonates: Intraspecies genetic distribution and prevalence of virulence factors. J. Clin. Microbiol., 41 (5), 1929-1935.

Waits, K. B., Katz, B., Schelonka, R. L. (2005). Mycoplasmas and ureaplasmas as neonatal pathogens. Clin. Microbiol. Rev., 1 (4), 757-789.

Received 17 March 2013

\section{MAKSTS BAKTERIOLOĢISKO IZMEKLĒJUMU KORELĀCIJA AR MAKSTS PH MĒRĪJUMU UN NATĪVĀS MIKROSKOPIJAS REZULTĀTIEM GRŪTNIECĪBAS PIRMAJĀ TRIMESTRĪ}

Pētījuma mērkis bija izanalizēt maksts uzsējumu korelāciju ar paaugstinātu maksts pH un izmainītu mikrofloru natīvajā mikroskopijā grūtniecības pirmajā trimestrī. Škērsgriezuma pētījumā tika iesaistītas 100 grūtnieces, kas laika periodā no 2010. gada marta līdz 2011. gada aprīlim apmeklēja piecas ambulatorās aprūpes iestādes Rīgā. Dalībniecēm pirmās antenatālās vizìtes laikā no maksts tika paṇemti paraugi izdalījumu pH mērījumiem, natīvajai mikroskopijai, kā arī uzsējumu veikšanai. Pētījumā tika iekḷautas 50 grūtnieces ar maksts pH $\geq 4,5$ un 50 grūtnieces ar maksts $\mathrm{pH}<4,5.96 \%$ sieviešu ar maksts $\mathrm{pH} \geq 4,5$ un $86 \%$ ar maksts $\mathrm{pH}<4,5$ bija pozitīvi uzsējumi $(P$ vērtība nebija statistiski ticami atškirīga). Patoloǵisks maksts pH un mikroflora bija statistiski ticami biežāk saistīti ar M. hominis $(P<0.001)$, U. urealyticum $(P=0.017)$ un $E$. coli $(P=0.018)$ pozitīvām kultūrām. Daudzfaktoru loǵiskās regresijas analīze parādīja, ka vislielākais risks saistíbai ar patoloğisku maksts mikrofloru ir M. hominis (OR 14.4, 95\% CI 1.6-124.4, $P=0.015)$ un E. coli (OR 8.5, 95\% CI 1.6-45.9, $P=0.013)$. Grūtniecēm pirmajā trimestrī palielināts maksts $\mathrm{pH}$ un patoloğiska maksts mikroflora natīvajā mikroskopijā ir saistîti ar M. hominis un E. coli pozitīviem uzsējumiem. 